\title{
Notice of Inscriptions and Antiquities, Discovered at Caerleon
}

\author{
John Edward Lee Esq.
}

To cite this article: John Edward Lee Esq. (1851) Notice of Inscriptions and Antiquities, Discovered at Caerleon, Archaeological Journal, 8:1, 157-162, DOI: 10.1080/00665983.1851.10850818

To link to this article: http://dx.doi.org/10.1080/00665983.1851.10850818

冓 Published online: 10 Jul 2014.

Submit your article to this journal $\lceil\pi$

Q View related articles $\longleftarrow$ 
use of imposts, the well-executed tenons and mortices, and the worked surfaces of the uprights, all seem to point to a later age, and a more advanced civilisation. I think therefore we may fairly conclude, that Stonehenge is of later date than Avebury and the other structures of unwrought stone ; that it could not have been built much later than the year 100 , B.c., and in all probability was not built more than a century or two earlier. As to the antiquity of Avebury, I dare offer no conjecture. If the reader be more venturesome, and should fix its erection some eight or ten centuries before our era, it would be difficult to advance any critical reasons against his hypothesis.

Notice to THe Reader.-Portions of the map which is attached to this paper are coloured yellow. They are intended to represent the district, that were retained by the Britons after the conclusion of the treaty of the Mons Badonicus, A.D. 520. The boundary lines, which, in certain localities, mark out the frontier, are supposed to have been constructed-or, it may be, in some cases, adopted-by the Britons upon that occasion.

\section{NOTICE OF INSCRIPTIONS AND ANTIQUITIES, DISCOVERED AT CAERLEON.}

COMMUNICATED BY JOIN EDWARD LEE, ESQ.

Numerous are the restiges of interest, connected with the history of Roman occupation in the ancient district of the Silures, which have repaid the researches of archaeologists in that part of the kingdom. Some of the discoveries recently made at Caerleon are not unknown to the readers of the Journal, whose attention may have been invited to the memorials of the antiquities and of an extensive villa there brought to light, noticed in previous volumes. ${ }^{1}$ The publications to which we refer will show the variety of these remains, and especially the value of the accession to the history of Roman times in Britain, as illustrated by inscribed monuments, derived from investigations of late years at Isca Silurum. Upwards of twenty inedited inscriptions have

${ }^{1}$ See Notices of "Roman Antiquities found at Caerleon," by John Edward Lee, Esq., 1848, and of his recent work, VOL. VIII. entitled, - "Description of a Roman building discovered at Caerleon."-Arch. Journal, vol. ii. p. 417 ; vol. vii. p. 97. 
been represented in these two publications. Several of these contributions to the "Britannia Romana" are of essential value and interest.

It will afford gratification to every lover of Archaeological science to be assured that the zeal of the antiquaries of Monmouthshire has not been limited to the exciting pursuit of explorations: the stimulus caused by the successful operations of the spade has produced a permanent and satisfactory result, the establishment of a suitable Museum, in which all these vestiges will be collected, and assume a far higher interest when preserved in their proper locality, and on the actual spot, of whose early history they form so invaluable a memorial.

The accompanying plates supply representations of some of the most recent discoveries on the site of the ancient $I s c a{ }^{2}$

The first comprises two curious additions to the series of inscribed monuments, one of them dedicated to Fortune, a goddess much esteemed and worshipped in Britain, as Horsley observes, in the times of Roman dominion, a great number of altars being found inscribed to her. ${ }^{3}$ The singular appropriation of the fragment of a stone conduit-pipe to such a purpose will not escape observation. Did we not perceive that it had been dedicated by an important officer, the prafectus castrorum, - the quarter-master of the legion, whose functions as we learn from Vegetius concerned the formation of the camp, and its internal economy, - the humble character of this tablet might lead to the supposition that it had been inscribed by some ignoble hand, or rural settler. We are reminded of the lines of Horace, regarding the popular cultus of Fortune,-

\section{“Te pauper ambit sollicita prece Ruris colonus,"}

The second inscription in the plate is of even greater value to the antiquary, as a fresh illustration of the prevalence of the worship of Mithras, even in these remote parts of the Roman world. The stone which bears this inscription seems

3 For these interesting plates the Society is indebted to Mr. Lee, who has liberally prepared and presented them to the Journal. This kindness is doubly welcome, when the researches of the archaeologists in South Wales must assume a fresh interest, as the coming visit of the Institute to Bristol will afford the occa- sion of inspecting these curious remains.

3 Britannia Romana, p. 233. See in that work several Notices of Altars to Fortune. Mr. Bruce, in his valuable volume on the Roman Wall, represents a remarkable example from Risingham, now in the Museum of the Antiquaries of Newcastle, p. 403. 

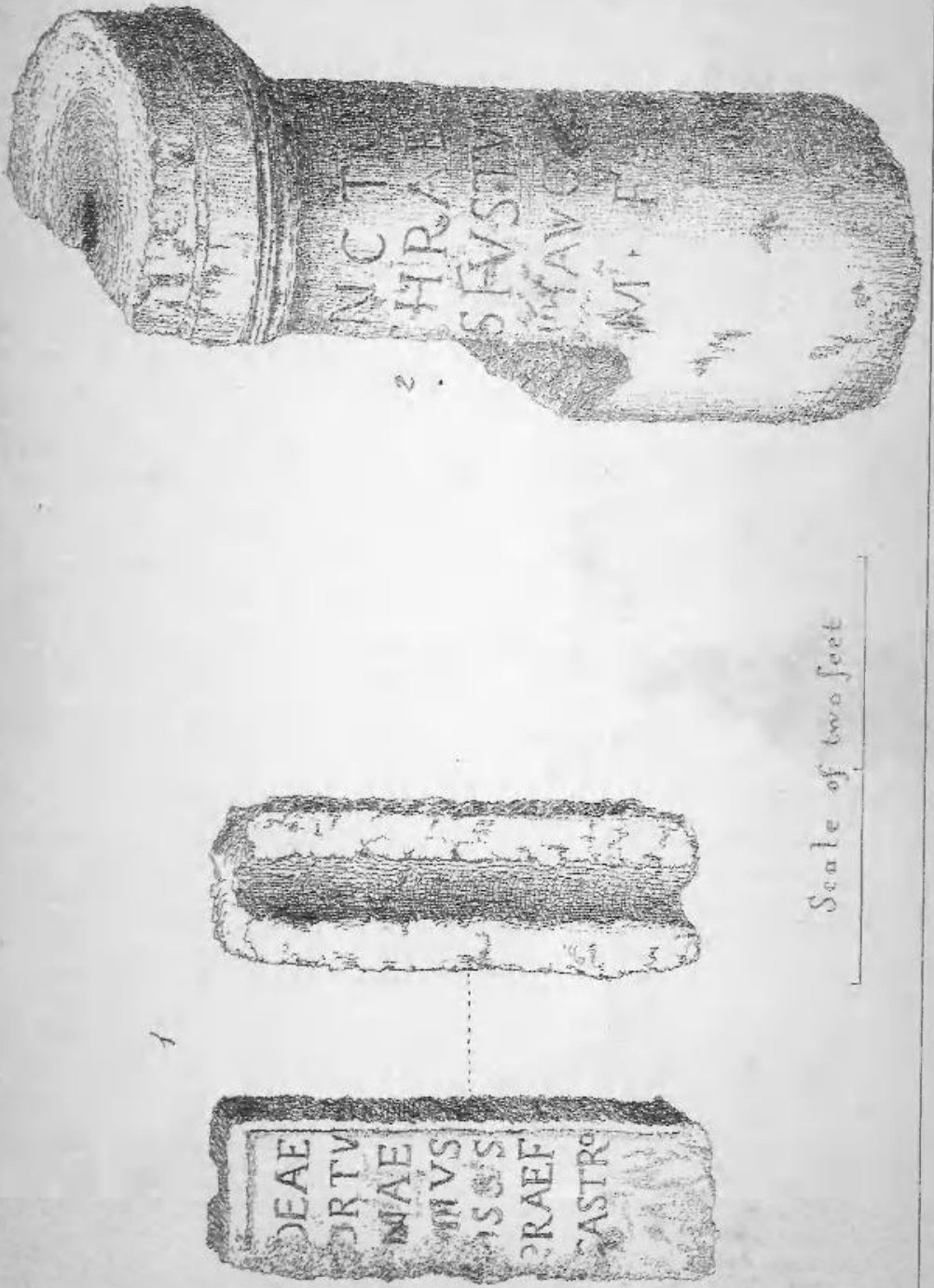

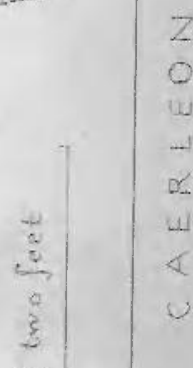

$$
\begin{aligned}
& \div \\
& \text { t) }
\end{aligned}
$$

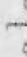

$$
\begin{aligned}
& \text { थ }
\end{aligned}
$$


to have formed part of a column ; it measures in height, 3 feet $8 \frac{1}{2}$ inches; diameter of shaft, 18 inches and two thirds; diameter of the widest part of the capital, 23 inches. The fragment of a pipe, first described, measures 27 inches by 9 inches, and its thickness is $6 \frac{1}{2}$ inches. Both are of oolitic stone, probably taken from the inferior oolite of the opposite side of the channel, in the neighbourhood of Dundry, or some adjacent locality.

During the approaching visit of the Institute to Bristol, those members who are versed in the study of RomanoBritish vestiges will, doubtless, be attracted by the assemblage of ancient relics lately brought to light at Isca. They will thus have occasion to examine the remains now submitted to the notice of the society ; and for the present, all endeavour to offer any reading of these inscriptions may be deferred. Several important traces of the worship of Mithras have been discovered in other parts of Britain, the most memorable being those deposited in a cave or cell, near the station of Borcovicus, on the Roman wall, and similar relics have been found in Cumberland. ${ }^{4}$ The usual formula, INviCTO MITHRAE, seems to be discernible on the Caerleon column.

The first relic represented in the plate of miscellaneous Roman antiquities is a fragment of a fictile vessel, of singular construction. It is of the common red ware, and the colour is unusually good. Small bottles of earthenware of a globular form, short-necked, and with one handle, are of ordinary occurrence amongst Roman remains; they may possibly be designated by the name laguncula. The peculiarity in this example consists in the partition which divided the vessel into two cells, probably for the reception of distinct condiments, like certain twin cruets of glass, well known to travellers in Italy, with a medial partition and two necks, serving to contain both vinegar and oil in one vessel. Unfortunately the fragment found at Caerleon affords no evidence in regard to the general form of the vessel, in its complete state : the representation here given is of the original size. Small earthen vessels, not very unlike the modern saltcellar, with a partition, have been found in Germany ; ${ }^{5}$ and

4 Of the sculptures found at Housesteads, Borcovicus, see the valuable Memoir by Mr. Hodgson, in the Archæologia Aliana, vol. ii., p. 263; Hodgson's Hist. of
Nortlıumb., vol. iii. p. 190; Bruce's Roman Wall, p. 407.

5 They occur with two, and with three cells.-Wagener, Handbuch, fig. 1070. 
Brongniart gives a jar with two ears, and divided by a "cloison longitudinale," found in Lusace, and another with three cells, from Saxony. These vessels, however, are not adapted for pouring liquids.

Fig. 2 represents a glass bead, of a dark orange colour when held in a strong light, but so opalescent by age, that the colour cannot otherwise be seen. It had four drops on the surface : the three here shown are of a light-coloured or nearly clear glass. Several varieties of these beautiful relics of ancient manufacture, found at Caerleon, have been figured in the "Delineations of Antiquities" there discovered, pl. xvi. An interesting memoir on this subject has recently been given by Mr. Akerman, in the "Archæologia," illustrated from the beautiful drawings of Mr. B. Nightingale.

Fig. 3.-An object believed to be unique amongst Roman antiquities found in Britain. It is a foot-rule of bronze ; the hinged joint is so fixed by rust that the rule cannot be opened to its full length, but the half measures a little more than 5 inches and eight-tenths, so that when extended the rule would exactly correspond with the Roman foot of 11,604 inches. There is a stay at the back, turning on a pivot, with two notches on the edge, to receive two studs on the opposite limb, so as to render the rule stiff, and prevent its closing when extended for use. An original bronze regula, precisely similar to this, was found in a mason's shop at Pompeii ; one side was graduated in 12, the other in 16 parts. Graduated rules appear on certain sepulchral tablets, represented with the compasses, chisels, and other tools. ${ }^{7}$

Fig. 4.-A small bronze spoon, commonly designated by the name ligula, of a form not unfrequently found with Romano-British relics. It appears suited to answer the purposes of a surgical probe. ${ }^{8}$ Some antiquaries have supposed them intended to collect the tears of mourners, and drop them into the lachrymatory. See one represented in the Cabinet de Ste Genevieve, pl. ii.

Fig. 5.--A small bronze fibula, of oval form ; the central portion presents a wry-mouthed visage, not very artistically chiselled: the little circles attached to the rim are orna-

- Traité des Arts Ceramiques, pl. 27, figs. $20,23$.

7 See one found at Rome, graduated in sixteen parts, amongst the Instrumenta fabrorum tignariorum. Gruter, l. c. p.
229. Another, Corp. Insc. t. i. p. 11, p. 644 .

8 See specimens found at Richborough and Lymne, "Antiqu. of Richborough," by Mr. Roach Smith, pp. 103, 261 . 
mented in the centre with vitreous paste or enamel, of a lead colour, or light dull blue, much decayed by time. Several enamelled fibulæ of beautiful workmanship have been discovered at Caerleon; some of these are represented in the "Delineations," before cited, plates xv., xvi.9 Amongst the numberless varieties of fibulce, several resembling this in fashion have been found in England, but the central visage is a novelty. The acus was of iron.

All these relics have been brought to light on the site of the extensive villa at $I s c a$, discovered recently on the property of John Jenkins, Esq.

Fig. 6.-A bronze fibula, of an unusual type, found some years since at Caerleon. It was bought by Mr. W. D. Evans, of Newport; but happily, like other relics from $I$ sca, it has been restored to the locality where it is doubly interesting, and is now in the Museum lately established at that place. A rectangular fibula of metal, of similar pierced work, was found in the remarkable deposit in Kelco Cave, near Settle, Yorkshire. $^{1}$ Fibulæ of different type, ornamented with somewhat similar triforiated work, have repeatedly been noticed amongst Romano-British antiquities. The unique silver ornaments found during the construction of the Ely and Peterborough railway, appear to have been wrought with pierced patterns of this kind. (Archaeol. Journal, vol. v., p. 219.) The same peculiar motive of ornament appeared on two bow-shaped fibulæ, found near Horsham, and in the collection of the late Frederick Dixon, Esq. Similar fibulæ, found with an interment at Sutton Courtney, were exhibited by Mr. Jesse King, in the Museum of the Institute, during the Oxford meeting. ${ }^{2}$ The peculiar type of decorative design, here seen, formed by a zigzag line, with intervening compartments, having an embattled appearance, deserves notice, as partaking of an Oriental character ; but more especially on account of its conformity with a conventional ornament of the borders in illuminated MSS. of the eighth and subsequent century, produced by the school of designers, which may be designated

${ }^{9}$ Several of these fibulæ, which may be classed with the best examples of Roman enamelled ornaments of this kind, were exluibited in the Museum of the Institute at the Lincoln Meeting, through the kindness of Mr. Jenkins, on whose estate at Caerleon so many curious relics have been disinterred, and by Mr. Lee.-Ed.
1 Collect. Antiqu. by Mr. C. R. Smith, vol. i., pl. 26 , p. 71 .

2 Amongst other examples may be cited one in Mr. Roach Smith's Antiqu. of Richborough, p. 81 , fig. 2 ; and another found near Shorne. Journal Archaeol. Assoc., vol. iv. p. 406. 
as the Hiberno-Saxon. The borders of the "Durham Book," date about 700, may suffice as an example. The like ornament occurs in early Irish sculpture, as also probably in metal-work.

The relics of Roman occupation in South Wales, thus briefly noticed in the foregoing remarks, may suffice to show how varied is the character of the vestiges of that remarkable people in this part of Britain, and how desirable an object has been contemplated, in supplying a permanent place of deposit for all antiquities which may be brought to light in a district rich in Historical and Archaeological recollections.

The two plates accompanying the foregoing notices have been very kindly prepared by Mr. Lee, and presented to the Institute, for the gratification of the readers of the Journal. They have been etched by himself, and faithfully pourtray some of the curious relics which have repaid his recent explorations at Isca. The Central Committee desire to express their thanks, in acknowledgment of this kindness on the part of an archaeologist who has achieved so much for the illustration of the antiquities of his country, and to whose laudable exertions is mainly due the establishment in that place of a very interesting local Museum.

NOTICES OF REMAINS OF A ROMAN CHARIOT, PRESERVED IN THE MUSEUM AT TOULOUSE.

BY THE LATE WILLIAM BROMET, M.D., F.S.A.

I Do not know that any detailed account has as yet been published of the remains of an ancient car, stated to have been discovered by Sir W. Lawson, in a tumulus upon his property in Yorkshire. The restored bronze car in the Vatican, the dissevered portions of another found by Lucien Bonaparte, at Canino (now in possession of his widow, and for sale), and a few fragments of one found in 1813, at Perugia, of which some are in the museum there, and some were in the collection of Mr. Dodwell, are the only real monuments of this kind now extant (unless, indeed, there be some fragments in the British Museum, and a wheel stated to exist 